\title{
THE MYSTERY OF THE K. PRENDERGAST MANUSCRIPT
}

\author{
by Don Squires, Michael J. Clarke and Sandra Freshney
}

\begin{abstract}
Squires, D., Clarke, M.J. \& Freshney, S. 2015 (18:xii): The mystery of the K. Prendergast manuscript. Papers and Proceedings of the Royal Society of Tasmania 149: 7-12. https://doi.org/10.26749/rstpp.149.7 ISSN 0080-4703. Tasmanian Museum and Art Gallery, Hobart, Tasmania 7001, Australia (DS*, MJC), and Sedgwick Museum of Earth Sciences, Brighton Building, Cambridge, England CB3 GEI (SF). *Author for correspondence. Email: squiresdon27@gmail.com
\end{abstract}

In the 1930 s a rising star in the constellation of Australian palaeontologists had been born. Hard working, attentive to detail and very bright, Kathleen Laura Prendergast seemed destined to attain a solid place in the high ranks of Australian geology. Winner of many awards and scholarships, she carried her academic career through to a PhD at Cambridge University. Then, abruptly her course changed and in a relatively brief time she gained an MD and served as a medical officer in the British Army. Left behind as a consequence of that career change were a manuscript and her research collections, the former seemingly important, possibly even critical to an evolving understanding of Permian brachiopods. That manuscript was thought to have been commenced, possibly finished, but then lost through misadventure. The star collapsed, but a myth remained. This paper is the result of an exploration of the trajectory of the career of Kathleen Prendergast. It attempts to resolve the story of the "lost" manuscript and an analysis of what might have been. This investigation involved The Royal Society of Tasmania and the Tasmanian Museum and Art Gallery, the Sedgwick Museum of Earth Sciences, Cambridge University, the Royal Society of Western Australia and the University of Western Australia amongst others.

Key Words: Permian brachiopods, Prendergast, Western Australia, Tasmania, Cambridge, England, Taeniothaerus subquadratus.

\section{THE STORY}

Kathleen Laura Prendergast was born in Carlton, Victoria, on 19 November 1910 to Mary Jane Fisher (née Betharas) and George Lucas Prendergast. A second daughter, Mary Betharas Prendergast, was born a year later. According to electoral records, the family moved about. In 1914, they lived in Black Rock, Victoria, where George was listed as a farmer. After his discharge from the military in 1919, the family is listed as living in Cheltenham. In the 1925 Electoral Roll, Kathleen's mother, Mary Fisher, appeared as a teacher in Maylands, Perth, Western Australia, and again in 1931 at Nedlands, Freemantle. George Lucas Prendergast died in 1932 in Perth. In the 1936 roll the two daughters, Kathleen Laura and Mary Betharas were living in Freemantle with their mother, who died in 1949 in St Kilda, Victoria (Glover 2013).

Kathleen Prendergast's first expressed career interest was the study of medicine, but when the opportunity for tertiary education at the University of Western Australia came to her, she selected geology as her field of study.

She graduated in 1933 as a BSc with Honours. During her Honours year she did palaeontological consulting work for the Freney Kimberley Oil Company then exploring the region of Permian outcrop in Western Australia. She had already gained a reputation for energetic and able work, but she was unable to get full-time employment in geology involving fieldwork, a not unusual situation for a woman in the early twentieth century. As an alternative to geological work, she considered teaching as a means of enhancing her and her family's income (Glover 2013).

Kathleen qualified for the Diploma of Education in 1935. That same year she was awarded a Hackett Research Studentship for the study of "The Permo-Carboniferous fauna of Western Australia”. After spending the first year at the University of Western Australia she requested and was granted a suspension for a year (about 1936) so that she could work as palaeontologist for the Freney Kimberley Oil Company. In 1937 she went to Cambridge University to complete her academic studies in palaeontology. In her first year she was awarded a scholarship by the Royal Commission for the Exhibition of 1851 which would provide monetary support for an additional two years. She was only the second graduate of the University of Western Australia to gain this honour (Anon 1937).

Why was Kathleen Prendergast stirring so much interest on her behalf?: "Miss Prendergast impresses with the work she is doing. She has undertaken a difficult job which demands infinite care, insight and patience. These qualities she undoubtedly possesses... It would be little short of a scientific calamity if so able a person were not allowed sufficient time to make fullest use of her opportunities" " "an outstanding Professor of Geology at Cambridge" [probably Owen Thomas Jones FRS, Woodwardian Professor at Cambridge, 1930-1943], Anon 1937, p.12).

In her 1935 Honours paper (Prendergast 1935) she described and figured 12 genera, one of which was new and ten species, four of which were new. Her descriptions were detailed, but she made no revisions of the taxonomy other than to note that many geologists were content to list fossil fauna of strata by pre-existing names without review. She revised incorrect but oft-repeated fossil identifications by geologists: as she put it poetically, but rather acidly, it was about:

[Some]... Creatures borrowed and again conveyed From book to book - the shadows of a shade. (Prendergast 1943, p.1)

In 1943 she published a longer paper, "Permian Productinae and Strophalosinae of Western Australia" (Prendergast 1943). This study, drawing on the expanded collections she had made while working with the Freney Kimberley Oil Co. and loans from various museums, not 
only broadened knowledge of the variety of the brachiopod fauna but, again, was critical of previous authors for simply using established names for the taxa. Further she amplified the morphological descriptions of many species particularly emphasising the character of the internal structures of the brachiopods which she illustrated with drawings. This work covered ten genera of the families considered, none of which were new. Twenty-seven species were described, seven of which were new. This research was, in our estimate, the basis for her PhD. dissertation. A copy of Prendergast's dissertation was not available to us for comparison. Our judgement is based upon the time of publication and comments, in passing, of her colleagues in Western Australia.

\section{CHANGE OF COURSE}

Following award of her PhD in 1939, Prendergast seemed to have planned to continue her research on the Permian brachiopods of Australia. She was supported in this endeavour by the funds from the 1851 Royal Commission scholarship. Rather than simply adding to her substantial contributions to the Western Australia Permian fauna, she obtained specimens from the Permian strata of Tasmania from several sources including the Tasmanian Museum and Art Gallery (TMAG). Her intention was signalled by a note in her 1943 paper. Following the brief diagnosis of the genus Taeniothaerus, she referred readers to an as yet unwritten paper:

For a description of this genus see Prendergast, Proc.

Roy. Soc. Tasmania (Prendergast 1943, p.27).

Although she was still thinking about her future research, other, seemingly more pressing matters were occupying her time and priorities. Sometime after 1939 Prendergast ceased her palaeontological research and commenced training in medicine culminating in a medical degree and certification in 1944 . We can only speculate on her motivation. Some of the brief biographies appearing in the media after her death suggest this was a reversion to her earliest interests in medicine, while others have suggested that she may have wished to serve England in the latter days of World War II. Whatever the reason for this change, upon completion of her medical certification she was appointed to the British Army of the Rhine (BAOR), with the rank of captain. Soon thereafter she was assigned as Resident Medical Officer (RMO), with the rank of major, to the Black Watch Regiment (BAOR). This was the first ever RMO appointment to a serving military unit made to a female by the British Army and the first ever to the Black Watch. While many thought that the placement of a female in that unit of such rugged reputation was a joke, the commander of the regiment rejected such thoughts and resisted attempts by the Army Medical Corps to reassign her elsewhere. Colonel Bernard Ferguson, regimental commanding officer, said of her: "... she wove herself quickly into the regimental fabric $\ldots$ and became expert in regimental programs" (Glover 2013 , p.7). This was substantiated by her being permitted to wear the "Red Hackle" in her bonnet as were other “outstanding personnel” (Glover, 2013, p.7).

Upon de-mobilisation in the autumn of 1953, Major Kathleen Prendergast was posted to the Cowgden Military
Hospital in Glasgow and died, seven months later, on 1 June 1954, of sarcoma of the lung (Statutory Deaths 644/18/05321 provided by scotlandspeople@ gro-scotland. gst.gov.uk). She is buried at the hospital cemetery.

\section{THE RESEARCH SHE LEFT BEHIND}

Before Prendergast left the field of palaeontology, she had begun to acquire the materials for what would be her third study of the strophalosid and productid brachiopods of Australia. It would have commenced about 1939-1940. She had undoubtedly seen some of the eastern Australian and/or Tasmanian specimens in the Sedgwick Museum at Cambridge and would use them to resolve issues that had troubled her in her doctoral studies (Hill 1950).

But she would require an expanded collection. There is no evidence that Kathleen had ever visited Tasmania, Victoria or eastern New South Wales. How and who she contacted in Tasmania to arrange for those additional materials has been more clearly defined by our investigations but there is little direct evidence of how those contacts commenced. It is probable that her professor at Western Australia was known especially through the royal societies of Western Australia and Tasmania. But, at that time geology was in a formative stage in Tasmania. The Tasmanian Museum and Art Gallery had yet to appoint a curator of geology and its collections were limited in scope. The University of Tasmania's Geology Department was only formed in 1947 (Jennings 1990) and the Geological Survey of Tasmania, initiated about 1900, was in "sorry condition" until about 1954 (Jennings 1976, p.76). Tasmanian geological studies were being undertaken largely by self-taught amateurs, often operating under the aegis of The Royal Society of Tasmania. Many of these amateurs displayed great talent. One such, a lawyer by formal training, but with a great interest in geology, was Arndell Neil Lewis, who had informal relationships to both the university and the museum. Lewis (1897-1943), born in Symmons Plains, Perth, Tasmania, was an avid naturalist, particularly of geology. He published 18 papers on the subject in the Papers and Proceedings of the Royal Society of Tasmania, was awarded the Society's Medal in 1935, and his memorial volume, The Geology of the Hobart District was published in 1946 by The Royal Society of Tasmania with public support. He was Lecturer in Geology at the University of Tasmania from 1927-1931 and active at that time at the Tasmanian Museum. He married Amy Stewart Hungerford in 1927. We believe that through Lewis's participation, the Tasmanian Museum and Art Gallery made the first loan to the Sedgwick Museum for Prendergast's study. That Lewis himself made a subsequent loan from his personal collection to Kathleen Prendergast is well documented by a letter from A.G. Brighton, Sedgwick Museum, to Mr. E.C. Lewis, Hobart, dated 23 May 1947:

I gather from a letter I have received from the Director of the Tasmanian Museum that all the specimens, whatever the labels, were collected by Dr. Lewis (Brighton 1947a). 
The number of specimens and their identification marks in each of these loans is not known as no records were made or preserved by the Tasmanian Museum and Art Gallery. However, the much later return of the specimens to their rightful owners, while presenting a substantial problem for Sedgwick Museum Curator Professor A.G. Brighton (1900-1988), known as Bertie throughout his professional life, resulted in a detailed accounting of the specimens being returned:

From the Tasmanian Museum:

From A.N. Lewis:

From "Lewis's Last Collection":

No label of ownership:

37 specimens

47 specimens

10 specimens

40 specimens

The phrase "Lewis's Last Collection" refers, we believe, to a collection amplifying those previously sent by Lewis, for it notably contained the best specimens of the productid Taeniothaerus. There had been communication between Prendergast and Lewis about the need for better and/or more specimens, especially productiid Brachiopods, only a few of which had been included in the earlier loans. Of the 37 specimens listed as Tasmanian Museum, only ten were other than strophalosids. Some of the Lewis collection specimens may have been transferred by Mrs Amy S. Lewis or H.C. Lewis (A.N. Lewis's brother) to the Tasmanian Museum and Art Gallery.

Freed from the pressure to prepare her doctoral dissertation for publication and preceding the onset of her medical studies, Kathleen completed her research on the Tasmanian specimens. We have evidence of this through specimens returned to the Tasmanian Museum and Art gallery marked as "figured" or "type" and by fragments of the manuscript known as the "Mystery Manuscript" or "The Lost at Sea Paper" (see below). That Prendergast believed she had completed this research and fulfilled her obligations to those who had provided the study materials is contained in her description of Taeniothaerus in her 1943 paper. Prendergast stated, under Remarks:

For description of this genus see Prendergast, Proc. Roy.

Soc. Tasmania. (Prendergast 1943, p.27).

That statement is a clear indication that the author has done the research; the manuscript with its descriptions and conclusions has been written and dispatched to Professor E. de C. Clarke, her mentor while at the University of Western Australia. Kathleen was apparently expecting Clarke to forward the manuscript to The Royal Society of Tasmania. But the latter steps of the process were conducted under constraint. Kathleen was busy with her medical studies. She apparently didn't fully inform Professor Clarke of her completion of the manuscript or when it was actually sent to him. Several years after it could be reasonably expected that the manuscript had arrived and been processed, it was still missing.

On 19 March 1947, A.G. Brighton wrote to E. de C. Clarke asking if the Prendergast manuscript had been published in Western Australia. This was an adequate passage of time for the publication to have completed (Brighton 1947 b). Clarke wrote back explaining that while Prendergast had sent three copies of the manuscript..."only the last of which reached us and that was devoid of title and plates" (de C. Clarke 1947). Thus evolved the "Mystery of the Lost Manuscript".

What is not explained is why E. de C. Clarke did not inform J. Pearson, director of the Tasmanian Museum and Art Gallery, and member of The Royal Society of Tasmania, of the arrival of the manuscript unless he was expecting a second shipment from Kathleen. That task was left to A.G. Brighton who wrote to Pearson in a letter dated 23 May 1947 (Brighton 1947c) that:

...such portions of the MS. of her paper written for the
Proc. Roy. Soc. [sic] Tasmania as managed to survive the
war risks of the voyage to Australia. I enclose also this
manuscript. I note from it that the specimen labelled
Taeniothaerus subquadratus (Morris). Topotype. P. 16
[sic](see p.7 of MSS.) was originally sent her by Dr.
Lewis, and I think it must be the particular specimen
about which Mrs. A.S. Lewis was enquiring when she
visited us last year.

\section{THE PRENDERGAST MYSTERY RE- EMERGES}

In June 1946 the Sedgwick Museum was re-awakened to the matters of Kathleen Prendergast's departure. In a letter to Kathleen, A.G. Brighton reported that, in the course of cleaning out space in the attic:

...three trays of your material, the labelled part of which belongs to the Tasmanian Museum and formed I presume the basis for your paper which is in the process of being published by the Tasmanian Royal Society... What shall I do with the stuff? (Brighton 1946).

It was suggested that on her next leave she might visit Cambridge and deal with the materials. On 26 July 1947, Bertie again wrote:

We wrote about the specimens mentioned on 13th June 1946 [a year previously] and mentioned the visit of Mrs. A.S. Lewis. Having had no answer from you so ...wrote to the Tasmanian Museum, Professor E. de C. Clarke and the Western Australian Geological Survey and sent back all your stuff. As far as I know this effectively deals with all the material, but I should be glad to have your opinion (Brighton 1947d).

A handwritten letter from Kathleen Prendergast to A.G. Brighton dated 20 July 1947 opens with an expression of surprise that she should have received a letter dated 13 June $1 / 76$ which she presumed was an error on the part of the author. Whether the year delay in her knowledge of the letter was inattention on her part or the often experienced delays in mail delivery as posting of personnel changed is not known. But Kathleen continued that "... an anticipated leave in September would be a good time to come up to Australia [sic] Cambridge" (Prendergast 1947). This is suggestive of Kathleen's awareness of her impending visit to Australia but which to our knowledge did not involve a stop at Cambridge. Kathleen's visit occurred in July 1949 and was reported in the Argus (Argus, Melbourne 1949) as a ... "flying visit [...] from [Duisburg] Germany, where she is [in a] Black Watch Highland Regiment". The article 
largely concerned her initial opinion of Australian males and her shopping plans. It is quite possible that Kathleen also visited her mother then living in a suburb of Melbourne.

From November 1946 until November 1947 there was a flurry of correspondence between A.G. Brighton, Sedgwick Museum, Joseph Pearson, Director Tasmanian Museum and Art Gallery, Mrs A.S. Lewis and Mr H.C. Lewis, both of Hobart, regarding the "disposition of the Tasmanian fossils which had been sent to Kathleen Prendergast for her studies". The archives of the Sedgwick Museum yielded 14 letters, none of which have appeared in the files of the Tasmanian Museum or of The Royal Society of Tasmania.

An additional correspondence of five letters between E. de C. Clarke, University of Western Australia, with the Director, Geological Survey of Western Australia, dealt with the disposition of specimens from the Prendergast collection. But even with this effort there were a substantial number of specimens left over and which were possibly, but not certainly, sent to the University of Western Australia.

\section{CONNECTING THE TASMANIAN MUSEUM AND ART GALLERY TO KATHLEEN PRENDERGAST}

In 1967 Michael Clarke was newly arrived in Australia from Ireland to his appointment as the first palaeontologist for the Geological Survey, Tasmanian Department of Mines. One of his first assignments was in the Quamby map area in northern Tasmania and was the commencement of a 26+year career of interpreting the stratigraphy and palaeontology of the Upper Carboniferous and Permian sedimentary rock series of Tasmania. While monitoring a bore hole in Quamby Brook area, he searched in Quamby Brook exposures and encountered a new and exceptional display of strophalosid brachiopods which would serve as a marker in the Early Permian strata of Tasmania. To document this faunule, he produced a monographic treatment of their taxonomy (Clarke 1969).

Being new to the country, he had not yet developed his own collection and was using, in part, reference specimens from the Tasmanian Museum and the Geology Department, University of Tasmania. Among the specimens from the Tasmanian Museum were several bearing both the Tasmanian Museum registration numbers (Z\#\#\#) and paper stickers marked PL\#\#. With one of those specimens was a small paper label stating that the specimens marked with the PL sticker had been identified by K. Prendergast. The name Prendergast was unknown to most Tasmanian geologists, but the spectre of an unpublished manuscript was interesting to Clarke. Was it unpublished, or just forgotten? If found, what matters might it contain that would present problems to later researchers? Clarke (1969) with the outstanding Quamby Brook strophalosid collection now in hand, reviewed in detail the tangled systematic history of the Australasian strophalosids. In so doing he preempted the problems that would emerge with publication of Prendergast's 1953 paper.
Michael Clarke's next encounter with the name K. Prendergast occurred later while he was reviewing P.J. Coleman's 1957 study of the Permian Productacea of Western Australia. In that paper, Coleman (1957) reviewed the taxonomy of the Productacea citing K. Prendergast's previous works. Michael Clarke, who had not previously seen the Prendergast studies (and did not until 2013), only remembers Coleman's work in passing. Twenty years later, retired from the Department of Mines and now an Honorary Research Scientist at the Tasmanian Museum and Art Gallery, Clarke was reviewing the Tasmania Museum's early acquisitions of Permian brachiopods. His remarkable memory for detail intact, he recalled seeing among those specimens some similar to those seen nearly 30 years earlier which bore the paper tag notation $\mathrm{P \# \#} \mathrm{and} \mathrm{a} \mathrm{label} \mathrm{citing}$ a pending Prendergast manuscript.

The original papers regarding the loan of specimens made to Dr Prendergast at the Sedgwick Museum following completion of her $\mathrm{PhD}$. work had not been preserved at the Tasmanian Museum and Art Gallery, but the Sedgwick Museum records detailed it when the specimens were returned in 1947. In a letter from A.G. Brighton to J. Pearson dated 23 May 1947. Brighton details what he had done in the distribution of specimens comprising the Prendergast loans, especially those of the "Lewis Collection". He confirms that E. de C. Clarke had sent "such portions of the MS written for the Proc. Roy.Soc [sic] Tasmania as managed to survive the war risks of the voyage to Australia" to him. He then raises the question of the specimen of Taeniothaerus marked "topotype" sought by Mrs. Amy Lewis. Importantly he notes that it appears on p.7 of the manuscript. Brighton also enclosed a one page comprehensive listing of the specimens borrowed by Prendergast now returned to the Tasmanian Museum (Brighton 1947e).

Surprisingly, the document accompanying the specimens returned by the Sedgwick Museum contained a listing of "Specimens associated with the above, but not definitely labelled Tasmanian Museum”. The new material from the east coast of Tasmania, suddenly broadened Prendergast's view of the Permian brachiopod fauna which, until then, had been of Western Australia only. It presented some interesting and puzzling new information. While M. Clarke had dealt with the strophalosids, there was a greater problem with the productiid Taeniothaerus.

Taeniothaerus is a genus of productid brachiopod found in the Lower and Mid-Permian strata of Australia with a more restricted range of occurrence in other countries. It was first described by Morris in 1845 based on specimens collected by Count P.E. Strzelecki in 1845 (Morris 1845). As is the case with many of these early collections in Tasmania, the actual site of collection is poorly described and the specimens were of indifferent quality. As a consequence, descriptions of these new genera and species were often brief. Attempts at re-collection often resulted in broadened misunderstandings of the taxa resulting in confusion and misuse of the names. Such was the instance with Taeniothaerus and its type species.

In 1928 F.W. Whitehouse proposed a new genus 
Taeniothaerus for a brachiopod based upon the nominated type species Productus subquadratus Morris, but he neither described nor figured the genus or species. Prendergast seized upon this and declared Taeniothaerus a nomen nudum (Prendergast 1935, p.17, footnote 1). This could have been well but for the International Rules of Zoological Nomenclature which permit the creation of a new genus without definition or illustration as long as a type species is nominated. This rather vague situation is how matters stood in late 1933.

Prendergast (1943) revisited the issue of Taeniothaerus giving a diagnosis of the genus and a description of its type species, T. subquadratus (Morris). While little is said of her previous convictions, she did note that in a stratigraphic sequence from the Fossil Beds, Irwin River, Western Australia, T. subquadratus might be a transitional form between Aulosteges baracoodensis and an unknown Productus. Then Prendergast (1943) described a new species Waagenoconcha imperfecta with "Productus subquadratus' Morris, Chapman, p.36" as a synonym.

\section{THE "LOST AT SEA" MANUSCRIPT APPEARS}

In 1950, P.J. Coleman, Senior Research Fellow, Geology Department, University of West Australia, wrote to the Sedgwick Museum (Coleman 1950) asking about the Prendergast manuscript "lost at sea during the war". A.G. Brighton (1950) responded that the "very incomplete" manuscript was at the Tasmanian Museum. Coleman then addressed the matter to the Tasmanian Museum with the following result:

Through the courtesy, of the Director of the Tasmanian Museum I have been able to study a rough draft of the lost paper, which confirms the diagnosis given. Because this draft may not have been the final expression of opinion, I do not feel at liberty to pass on any other results of her work, except to say that it does confirm the difficulty involved in the re-study of the type species, caused by the above complications. (Coleman 1950 p.85)

Coleman (1957) discusses Taeniothaerus and repeats Prendergast's conclusions. On p.86 he discusses her problems with the "poorly preserved" specimens of Western Australia and the broad [implied] use of descriptions of subquadratus by authors from Queensland and New South Wales. He then states:

Prendergast was able to procure additional material from the general locality given for the original specimens of subquadratus [The Lewis collection]. On the basis of this she completed her study and gave the diagnosis given above [that of Prendergast 1943, p.27]. Most unfortunately the manuscript containing the results of this work was while in transit to the Royal Society of Tasmania lost at sea during the last world war. She had, however, incorporated the diagnosis of Taeniothaerus in another paper (Prendergast 1943).
Dorothy Hill (1950) made substantive corrective actions to the taxonomy of Taeniothaerus though she considered it a subgenus of Aulosteges. She illustrated (photographically) for the first time, the type specimen of Productus subquadratus Morris lodged in the British Museum (Natural History), and, she gave the type locality of T. subquadratus more definitively than the "Tasmania", which the Lectotype [BM(NH) specimen 91171] was labelled. She also quotes A.N. Lewis's maps as suggesting that the Strzelecki locality was probably the fossiliferous limestones outcropping about the Glenorchy reservoir (Hill 1950, p.7).

But, it was not until Susan Parfrey's 1983 study that Taeniothaerus was completely understood. She wrote:

Previous descriptions of $\mathrm{T}$. subquadratus (Morris)

have not been based on the type specimens, but were made from material collected elsewhere in Australia and considered to be T. subquadratus. (Parfrey 1983, p.290).

She continues with a new and detailed description based upon both collections from type localities and on excellent specimens from new Tasmanian localities, such as the Enstone Park Limestone at Elephant Pass, the Peter Limestone at Friendly Beaches and Counsel Creek Formation at Maria Island. Some of the numerous specimens depicted are also ones studied by Prendergast: Figure 2A,B,D, Figure 3D, Figure 4.

\section{A FINAL NOTE}

Much has been learned about the "Prendergast Mystery" in the course of this investigation, but not all has been resolved:

1. The missing ("Lost at Sea") manuscript is still missing. But it has been tracked from its war-time trans-Atlantic crossing to Nedlands, Western Australia, and through shipments from the University of Western Australia back across the Atlantic to the Sedgwick Museum, and again to the Tasmanian Museum and Art Gallery and to the University of Sydney and then who knows. The last resting place of that "fragmentary MSS" may be at Sydney (if P.J. Coleman failed to return it), or at the Tasmanian Museum and Art Gallery (if he did). However, the questions raised by its being "missing" have largely been resolved.

2. The specimen of Taeniothaerus subquadratus (Morris) sought by the Lewis family was sent to the Tasmanian Museum and duly registered as specimen Z217 in one of its catalogues. It is quite probable that the specimen was later retrieved by either A.S. or H.C. Lewis from among the specimens returned from the Sedgwick Museum as had been suggested by Director Pearson. The specimen has not been located in the museum's collections. But the absence of a card with that number in the card catalogue started in or about 1935 by Dr Maxwell Banks, who when newly appointed to the Geology Department, University of Tasmania, also worked, part-time, as the first to curate the palaeontology collection, Tasmanian Museum, is taken as an absence of the specimen in the collection. If that is so, the specimen is now either in the possession of a Lewis family member or misplaced. 
But the story of Kathleen Prendergast has been told in its entirety and the myths associated dispelled.

\section{ACKNOWLEDGEMENTS}

For assistance in searching archives and records of the Royal Society of Tasmania we thank Lynn Davies, Natasha Watts and Heather Excell, librarians and researchers at The Royal Society of Tasmania Library, Morris Miller Library, the University of Tasmania. Jo Huxley, Research Officer, Tasmanian Museum and Art Gallery, provided guidance to its records. For assistance in computer searches and genealogical research, we thank Marian Steinberg, Research Assistant.

\section{REFERENCES}

Anon 6/6/1937: Successful Student/ 1851 Scholarship Award/ Honour to Miss K. Prendergast. The West Australian, p.12. Argus (Melbourne) 21 July 1949, p.7, 9.

Brighton, A.G. 1946: Letter from A.G. Brighton to Kathleen Prendergast dated 13 June 1946. The letter is addressed to 'Mick' as Captain K.L. Prendergast, R.A.M.C., 147 (B.R.) Field Ambulance, B.A.O.R. Sedgwick Museum of Earth Sciences: University of Cambridge, reference 312c.

Brighton, A.G. 1947a: Letter from A.G. Brighton to F.C. Lewis dated 23 May 1947. Sedgwick Museum of Earth Sciences: University of Cambridge, 1947 reference 312c.

Brighton, A.G. 1947b: Letter from A.G. Brighton to E. de C. Clarke dated 19 March 1947. Sedgwick Museum of Earth Sciences: University of Cambridge, reference 310c.

Brighton, A.G. 1947c: Letter from A.G. Brighton to J. Pearson dated 23 May 1947. Sedgwick Museum of Earth Sciences: University of Cambridge, reference 312c.

Brighton, A.G. 1947d: Letter from A.G. Brighton (signed "Bertie") to "Mick" dated 26 July 1947 and addressed to Capt. K.L. Prendergast, 1011 C.R.S., B.A.O.R. Sedgwick Museum of Earth Sciences: University of Cambridge, reference 312c.

Brighton, A.G. 1947e: Letter from A.G. Brighton to J. Pearson dated 23 May 1947. Sedgwick Museum of Earth Sciences: University of Cambridge, reference 312c.

Brighton, A.G. 1950: Letter from A.G. Brighton to P.J. Coleman dated 2 March 1950. Sedgwick Museum of Earth Sciences: University of Cambridge, reference 312c.

Clarke, E. de C. 1947: Letter to A.G. Brighton dated 25 March 1947. Sedgwick Museum of Earth Sciences: University of Cambridge, reference 310c.
Clarke, E de C, Prendergast, K., Teichert, K.L \& Fairbridge, R.W 1951: Permian succession and structure in the northern part of the Perth Basin, Western Australia. Royal Society of Western Australia 35: 31-84.

Clarke, M.J. 1969: Tasmanian Strophalosiidae. Tasmania Department of Mines, Geological Survey Report 10:51 pp.

Coleman, P.J. 1950: Letter from P.J. Coleman to A.G. Brighton dated 21 February 1950. Sedgwick Museum of Earth Sciences: -University of Cambridge, reference 312c.

Coleman, P.J. 1957: Permian Productacea of Western Australia. Bureau of Mineral Resources, Geology and Geophysics, Australia 40: 1-157.

Glover, J.E. 2013: The unusual career of Kathleen Prendergast, WA palaeontologist and Major in the Black Watch. West Australia Geologist 498: 6-9.

Hill, D. 1950. The Productinae of the Artinskian Cracow fauna of Queensland. Papers of the Department of Geology, University of Queensland 3: 1-36.

Jennings, I.B. 1990: Maxwell R. Banks AM, DSc. Geology in Tasmania - A Generalist's Influence. A Symposium Convened by the Geological Society of Australia (Tasmania Division) in Honour of $\backslash$ Maxwell R. Banks. p.7.

Jennings, I.B. (Compiler) 1976: History of the Geological Survey and Geological Survey Branch, Department of Mines, Tasmania, In Johns, R.K. (ed.) 1976. History and Role of Government Geological Surveys in Australia. Printed by A.B. James, Government Printer, South Australia: pp.57-63.

Lewis, A.N. 1946: The Geology of the Hobart District. A.N. Lewis Memorial Volume. 216 pp., figs., maps. The Royal Society of Tasmania, Hobart: 216 pp.

Morris, J. 1845: Description of Fossils in P.E de Strzelecki, Physical Descriptions of New South Wales and Van Diemen's Land. Longman, Brown, Green and Longman, London: pp.270-291.

Parfrey, S.M. 1983: Redescription of the Permian aulostegid brachiopod Taeniothaerus subquadratus (Morris 1845), the type species of Taeniothaerus Whitehouse. Memoirs of the Association of Autralasian Palaeontologists 1:289-296.

Prendergast, K.L. 1935: Some Western Australian Upper Palaeozoic Fossils. Journal of the Royal Society of Western Australia 21:9-35.

Prendergast, K.L 1936: Notes on the types of Spirifer notalous Hosking. Journal of the Royal Society of Western Australia 2:129.

Prendergast, K.L 1943: Permian Productinae and Strophalosinae of Western Australia. Journal of the Royal Society of Western Australia 28:1-73.

Prendergast K.1947: A handwritten letter addressed to Bertie (A/G. Brighton) and signed 'Mick' dated 20 July 1947. Sedgwick Museum of Earth Sciences: University of Cambridge, reference 312c.

(accepted 6 October 2015) 